\section{E A Institute of \\ yK Business Administration \\ तर Karachi \\ Leadership and Ideas for Tomorrow}

Article 1

Volume 9 Issue 1 January-June 2014

$1-1-2014$

\title{
Front Matter of Volume 9 Number 1
}

Tufail A. Qureshi

Institute of Business Administration, Karachi

Follow this and additional works at: https://ir.iba.edu.pk/businessreview

Part of the Business Commons

c) (i)

This work is licensed under a Creative Commons Attribution 4.0 International License.

\section{Recommended Citation}

Qureshi, T. A. (2014). Front Matter of Volume 9 Number 1. Business Review, 9(1), 1-13. Retrieved from https://doi.org/10.54784/1990-6587.1224

This article is brought to you by iRepository for open access under the Creative Commons Attribution 4.0 License and is available at https://ir.iba.edu.pk/businessreview/vol9/iss1/1. For more information, please contact irepository@iba.edu.pk. 
Volume 9 Number 1

January - June 2014

\section{Business Review \\ Leadership and Ideas for Tomorrow}

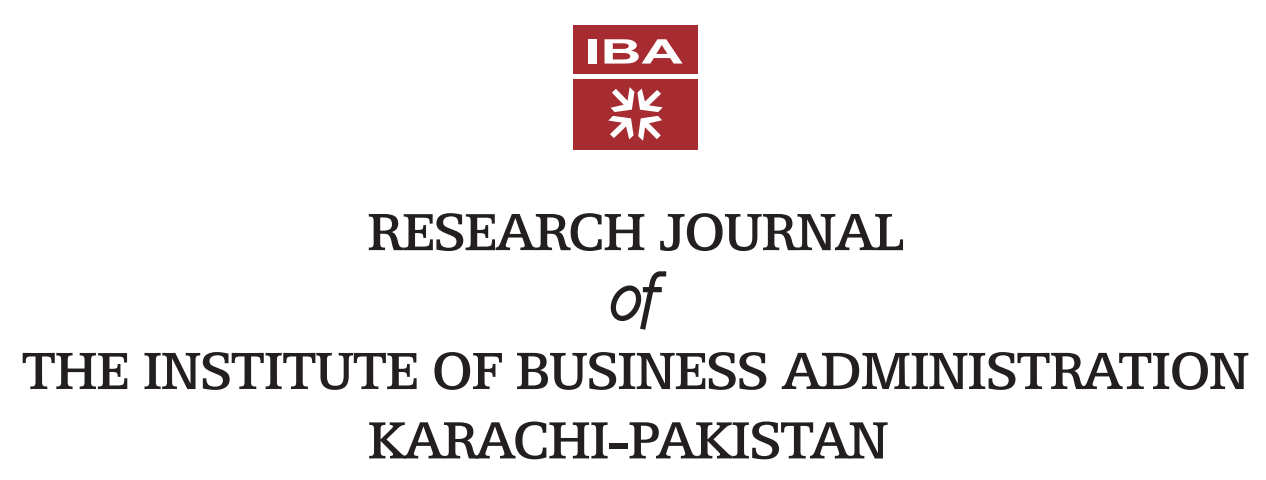


https://ir.iba.edu.pk/businessreview/vol9/iss1/1

DOI: https://doi.org/10.54784/1990-6587.1224

\title{
IBA \\ 掞 \\ त्रK
}

\section{BUSINESS REVIEW}

\author{
Volume 9 Number 1
}

January - June 2014

\section{INTERNATIONAL EDITORIAL BOARD}

Ishrat HUSAIN

Chairman Board of Editors

Deepak KAPUR

Institute of Management Technology Ghaziabad, UP, India

Khurshid M. KIANI

Bang College of Business, Almaty Republic of Kazakhstan

S.W.S.B. DASANAYAKA

University of Moratuwa, Sri Lanka

Menno ADEN

Technische University, Dortmund Germany

Liu Jun YING

Jinanjin University, Jian Jin, China

Naved AHMED

Institute of Business Administration, Karachi, Pakistan

M. Aminul ISLAM

University Sain, Malaysia

Bettina ROBOTKA

Humbolt University, Berlin Germany

Akif HASSAN

Iqra University, Karachi-Pakistan

Khursheed OMER

University of Houston, Downtown Texas USA

Zeenat ISMAIL

Institute of Business Administration, Karachi-Pakistan

Huma BAQAI

Institute of Business Administration, Karachi, Pakistan
Tufail A. QURESHI

Editor

\author{
Arun Diwaker Nath BAJPAI \\ Rani Durgavati University, Jabalpur, (MP) India \\ Talat A. WAZARAT \\ Institute of Business Administration Karachi-Pakistan \\ Shamas-ur-Rehman TOOR \\ University of New South Wales, Australia \\ Khadija Malik BARI \\ Institute of Business Administration Karachi-Pakistan \\ Ahmed Audu MAIYAKI \\ Bayero University, Kano Nigeria \\ Agung NUGROHO \\ Atma Jaya Cotholic University, Jakarta, Indonesia \\ Faisal Manzoor ARAIN \\ Southern Alberta Institute of Technology Canada \\ Low Sui PHENG \\ National University of Singapore \\ Badar Alam IQBAL \\ Aligarh Muslim University Aligarh,(UP) India \\ Abdul RASHID \\ Intrnational Islamic University, Islamabad-Pakistan \\ Mirza Sardar HUSSAIN \\ Institute of Business Administration, Karachi-Pakistan \\ Nadir Ali KOLACHI \\ Sky Line University, U.A.E
}

Business Review is a peer reviewed bi-annual research journal of the Institute of Business Administration (IBA) Karachi. It is recognized by the

Higher Education Commission (HEC) of Pakistan and is internationally abstracted/ indexed in the Journal of Economic Literature (JEL) and EBSCO database. 


\title{
BUSINESS REVIEW
}

\author{
IBA \\ Y्रK
}

RESEARCH JOURNAL

of

THE INSTITUTE OF BUSINESS ADMINISTRATION

KARACHI - PAKISTAN 


\section{CONTENTS}

Editorial Perspective

\section{ARTICLES}

A Study of Environmental Constraints faced by Public Private Partnership (PPP) in India and The Road to a Framework for Successful Implementation of PPP Project M.S. Khan

Determinants of Trade Balance: A Comparison between Pakistan and India Aurangzeb, Khola Asif

The Impact of National And Organizational Cultural Differences on International Joint Venture Performance

Rizwan Tahir

Interdependence of Value Chain Links: A Tale of Three Cities

Muhammad Rizwan Saleem Sandhu, Muhammad Zaheer

Perceived Importance of Job Analysis Influencing Motivation And Competencies Among Blue-collar And White-collar Employees

A.K.M. Mominul Haque Talukder

\section{DISCUSSION}

Educational Poverty by Design: A Case of Mismanagement of National Resources Nisar Ahmad

Learning New Management Viewpoints: Recontextualizing

Strategic Leadership in Global and Regional Context

Ahmad Raza, Hasan Sohaib Murad

\section{CASE STUDY}

Lays Halal/Haram Crisis

Jami Moiz, Nida Aslam Khan

BOOK REVIEW

The African Genius : An Introduction to African Cultural and Social History, Basil Davidson

Tufail A. Qureshi 


\section{Editorial Perspective}

World within World: Adjacent Realities

... the world does not merely have one meaning, the one disclosed by the sciences. The meaning of the world disclosed by the sciences is merely one among many. This meaning clings to the questioning attitude that is specifically proper to the sciences. The everyday world of life (Lebensewelt) however, is infinitely richer, for man is involved in the world through innumerable attitudes, so that innumerably many meanings impose themselves upon him.

Luijpen, W.A. Phenomenology and Metaphysics, p. 62

In his autobiography, World within World, Stephen Spender writes: "I do not know whether it is usual to teach philosophy as I was taught it.”. . (p. 36). It is a fraught question, if it is a question, not so much for academic reasons as for political ones. It is a vexing question, not for political reasons but for pedagogical ones. In any case, it is a good question and the answer depends on whom you ask. In Corporate Pakistan, for instance, it will be more appropriate to ask whether in our institutions of higher education philosophy is taught at all. In our barren academic landscape to find one good student of philosophy is good luck, to find two is very good luck but to find more than two is witchcraft. In 66 years of our chequered history, how many leaders have we produced? They we could admire and respect as men of wisdom and sagacity, knowledge and virtue, dignity, integrity and character?

We have not produced many because we do not need any. And yet our corporate landscape is so overcast with adroit minds, excited gibberish and animated vulgarity. We live in times of celebrations, celebrating our liberation from rational, civilized and cultural, ethical and moral constraints. These are the times to mourn the sad demise of discourse, the times when intellectual leaders and mentors dither and dare not to think, much less to speak. In times such as these, caution and expediency puts us to sleep, rather than rousing us from dogmatic slumber. We do not ask many a questions, for fear of painful answers. We need to wake up:

To find that the utmost reward Of daring should be still to dare

Trial by Existence: Robert Frost

To find, by reimagining the Corporate World, that in such visualization experiences, many layers exist in a single image, converging upon a wide variety of subjects - family and school, ethics and morality, politics and culture, present and future, fate and destiny, life and death, acquiescence and creative rage - layers within layers, world within world. 
The world we have been thinking about and rambling through is the romanced world of a philosophically minded Corporate Thinker. It is a world of sharply nuanced narratives, both in verbal and figurative sense. The discourse, comprising of these narratives, is spread over the entire corporate landscape. Corporate reality has many faces and each one of these narratives adds to the gestalt an unity, which, we are aware, transcends any given profile of the corporate world.

Our Corporate Functionary does not feel very comfortable with such descriptive expressions as "world within world." He thinks these are imaginative or poetic metaphors. He is right. But, it is also true that, in fact, his observation reflects the paucity of the corporate language, bereft of ideas and ideals, existential predicaments and humanistic intuitions. Corporate language is replete with numbers, percentages, ratios, proportions, symbols, figures, charts and diagrams etc. In the corporate world, كروباركونيا children are born in fraction, they live, suffer and die piecemeal; they are numbers not humans.

The word play in World within World is inspired by the phrase's evocation of folding in on itself. That is what makes it such an effective metaphor, like,

$$
\begin{aligned}
& \text { آثين ور آثينه، افنان ور افانا }
\end{aligned}
$$

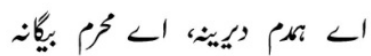

But there is a logical paradox inherent in the evocation, similar to the belief that the world of tomorrow will boomerang and rebound past the barriers and adversities and change the world of today. Such a belief may not change the past the future but when it fuses into our own identity, scripting an autobiographical narrative, it is likely to reflect reality and truth and quite powerfully condition what we desire, even if it is not desirable. Let us call it the pragmatic paradox. The conflict between desire and desirable (as value) converges upon human nature with the subterranean forces submerged in human consciousness. These forces, if they are not creatively, morally and transcendentally managed and used for remaking man and man's-being-in-the-world and if they are not predicated on truth, can destroy man many times over. The hyphenated phrase comes from Martin Heidegger's Being and Time p.78, and it must be seen as a compound expression. It is intended in contrast to the specialized notions about human nature, held by various sciences, that man's-being-in-the-world is an existential predicament and almost a moral condition.

That is the domain where Corporate Executive is bound to feel his existential solitude. That is the time when his interface with himself makes it more vibrant and daring. That is when he understands the anguish of "a moral person living in an immoral society." It is a lonesome life, as that of a "long distance runner". In the teaching and in research too, it is a lonely endeavor; almost pedestrian. But to go anywhere at all, you must go all the way, alone.

Pragmatism rest upon its central thesis that whatever works is true. The Pragmatist measures the meaning of truth on the success scale of workability. A little reflection reveals that it is not just a pragmatic proclivity; it is also Machiavellian temptation for expediency and a nuanced Darwinian narrative on survival of the fittest. To be a pragmatist, however, one must demonstrate acceptance of its thesis with regard to the place of truth and value in corporate discourse. 
Equally paradoxically, in the worlds dominated by "scientism" and "behaviorism" reality is measureable and quantifiable reality; it is what the thermometer can record and not the distress you feel when you are suffering from high fever. A behaviorist is not interested in the lived-world; little does he know about experienced reality. Observable facts and overt behavior is all that we need to know to theorize about man and his nature. James E. Royce, in his book Man and His Nature, has asked the question: "How can you tell whether a being is human or not?” (P.4). It is a question that reverberates throughout 398 pages of the book.

\section{The answer?}

A more inclusive and flexible paradigm of human nature is called for if it is man in his infinitive mystery that one wants to fathom.

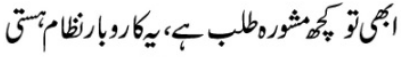

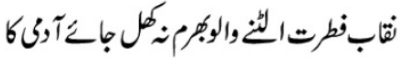

Human nature is a broad term. It includes logical, instinctive and socio-cultural tendencies. It involves moral and aesthetic values that are an integral part of hum personality. Our understanding of human nature involves the time honored way of developing a sense of how these forces play out in the life of man. The ontogenetic evolution of man extends beyond the biological evolution into the realms of music, art, poetry and literature as the essential components of a well-rounded personality. So, how natural is human nature, is a question that must be answered with certainty if our understanding of the World within World is going to have any meaning at all. It is an aspect of man's being-in-the-world as a human being. It is a heroic moral search for the meaning of man's being in the world. As a human being, man has his being in the world in the mode of becoming in the manner of transcendence. He is in the world not the way a chair is in the room. A chair cannot think, decide, choose, or desire to be something else, better than a chair or walk out of the room, to be somewhere else. A chair is condemned to remain a chair and in the room, forever. The search for the meaning of human nature converges upon the sense of the preposition in. Therein lies the whole mystique of the two worldviews. If the Corporate World goes to pieces, it will not be because all the Enrons collapsed but because we failed to formulate a satisfactory concept of the nature of man; as a human being.

The paucity of corporate language and the quantitative and measureable concept of reality in the corporate worldview is responsible for a great deal of obfuscation and dehumanization of human nature. In the Corporate World, which exists within our world as an adjacent reality, life is measured in terms of "profit and loss", contrary to our belief that life, as it is lived, surpasses and transcends such mundane considerations. Life, as an existential predicament, is a radical self-understanding and self-becoming in an absolutely non-adventitious consciousness of life.

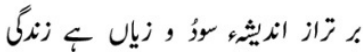

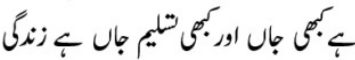

But we must respect the Corporate Functionary for being a good disciple of Wittgenstein, the exponent of linguistic philosophy and the author of Tractatus LogicoPhilosophicus. "The limit of my language," said Wittgenstein "is the limit of my world". Indeed. Our construction of reality and our imagination of the world, as Piaget has amply 
demonstrated, depends upon the language we speak and the way we intend the meanings of the words we use and that human nature, in the concrete, is a product of socio-cultural and linguistic development.

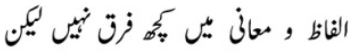

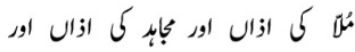

The second aphorism of Wittgenstein's reflections on the relationship between language and the world is that "whereof we cannot speak, thereof we must remain silent." Of course, this is not an excuse for mysticism; rather, it is an expression of our knowledge and understanding of the worldliness of the world. The world does not exist; only the worlds exist. The world is a vacuous concept; empty and without percept. It does not belong to anyone and no one belongs to it. It has no adjectival qualification. It is not yours or mine, ethical or moral, progressive, dynamic, retrogressive, good or evil just or cruel . . . Not the world but the worlds exist and corporate world is one of these many worlds. Hence the pluralistic idiom. Only the worlds exist and the worldliness of each world, existing within the world, is a relative fact, relative to the world as a lived world. It is a contingent possibility and not a permanent reality.

In our very simple epistemology, corporate world covers the totality of man's beingin-the-world. Corporate is an adjective and its meaning is not very easy to articulate. It is a word added to the world, i.e., to the noun. As such it describes a quality or modifies a meaning. Hence, not just the world but the corporate world. The noun or prefix changes the meaning of the world. The world, therefore, has no meaning and does not exist without an adjectival qualification. We live, each one of us, in a world which belongs to us and to which we belong. We, all of us, live not in different worlds but in the same world differently, in worlds within the world.

That is the context in which our thinking about man and the world must take place. Each world, including the corporate world, is subject to its inner laws of development and these laws, in addition to the coefficient adversities of the surrounding circumstances, determine the range and the extent within which an individual can become what he is capable of becoming. The emphasis on capability is meant to put in perspective the "freedom of will" and "the way we ought to act".

The critical premise here and the underlying sentiment is the convoluted belief that we are free to act in whatever way we like. It is a narrative that must be challenged with the full force of creative imagination and the will to truth. Let us take it for granted and let us show that we have the creative ability to transform the is into ought and the fact into value to know the difference such a mindset will make in our being in the world. Let us live dangerously, i.e., creatively and find out how much damage it can do to our being in the world. So, the "world within world" is not such an offensive phrase after all. It is a nuanced and biased motif of our Corporate Thinker who is a phenomenologically biased person committed to rethink his thoughts and reimagine the world. As a methodological device, such a radical attitude is necessary to face our subjective impediments and the adversities of our existential situation to become wiser to the world. Our Corporate Functionary eschews thinking and has no patience for retrospective wisdom. He has not constructed an official narrative which may be considered a methodological device for engaging in a radical critique 
of the way the corporate world is and a radically justified knowledge of the way it ought to be. It is a question of unified and unifying vision, transcending both, the thus it is and thus it ought to be towards the yet to be, in search of the world to be. The Corporate Functionary need to construct a narrative which has both in-depth meaning perspective. كيرانَ

Professionalism demands a radical change in our attitude towards the existing corporate paradigm, if we hope to enlarge and deepen our corporate worldview. To this end, we need a language that can sustain the dynamic variations of a constantly changing world; its permanence in change. A language that is, as a spoken language, prone to acquiescence and status quo, creates the feeling that life is on hold and transcendence, movement, meaning, value, change and growth have all withdrawn and fled from the world. Little wonder, we feel as if we are living in an environment which, in its surrounding, is a linguistically determined world. What our Corporate Functionary has to do as a professional imperative, is to construct a personal narrative with a pluralistic idiom and with the whole fabric of his thoughts, ideas and emotions, creatively woven around his motif, with all his intended rationalizations built into the imaginative vision of the world.

$$
\begin{aligned}
& \text { كـ آور بـ جه اندر بين وارى } \\
& \text { كرو }
\end{aligned}
$$

Remembering that only worlds exist and these worlds are adjacent realities, existing within the world; each one of them a world within world. It is a substantive phenomenological observation that none of these worlds have fixed or permanent boundaries or demarcations, other than those drawn by creative imagination. They overlap and intercede dialectically enriching and being enriched incrementally by participating in the shared meaning structures, value judgments and moral order. These worlds are constantly changing in a changing world, acting and being impacted upon each other, struggling to enlarge their sphere of influence by narrowing down or ignoring altogether, the territories and the landscape that belongs to the adjacent world or worlds. Frictions arise and conflicts emerge when the worlds clash and intrude into the adjacent worlds. The primary causes of cognitive dissonance, emotional aberrations, attitudinal dispositions, biased assumptions, prejudiced and unexamined beliefs and ideas are inherent in their nature and flawed worldview.

The world is an inclusive category; it embraces the worlds, including the corporate world within its fold. It has a much larger nomenclature than any of the worlds which are circumscribed within as in an environment, like circles within circle. Diagrammatically, we find their symbolic exposition in deductive logic in the form of categorical syllogism. Corporate world invites generalizations and our Corporate Thinker is not averse to the notion that the reality philosophers have been searching for, has become, with the passage of time, Corporate Reality. In the realm of political and social action, it sounds like a thought from P.D. Ouspensky's In Search of the Miraculous (Chapter 1), but we need not venture to step into any mysterious domain. In search of the possible contours of the possible world, the world as it ought to be, the world to be, mere enthusiasm, idealism mystifications, good intentions or metaphysical flights are not enough. In search of the Corporate Reality they cannot point the right path and not even the right direction, in our search for the desired goal and in our quest for the desired end. Therefore, instead of indulging in metaphysical flights, we must remain true to the earth, as Nietzsche and Iqbal would like us to do. In search of a new perspective on corporate world, we need to make ourselves understand that due to 
our complacency, the forces, compulsions and propensities inherent in the taken for granted attitude have taken over our narrative by incorporating the linguistic and ideational structures conceptual and symbolic terminologies into "it goes without saying" discourse. More significantly, as we see in the Corporate Pakistan, the conflicts, contradictions, mutually exclusive and seemingly categorical structures coexist and overlap the interdependent and relatively independent meaning structures - not metaphorically but actually and literally. A radical examination and a phenomenological reduction of the naturalistic attitude is an extremely engagement situation and an onerous task, taxed with the burden of reconstructing the corporate world, while living in it as a world within world. It is hard but there is something heroic about the search for the moral meaning of thus it ought to be. It is a contentious task the Corporate Functionary has to face today. To retrieve and refashion the terminology that has already absorbed the biases and prejudices by being part of the language of the "given" corporate world is an onerous but extremely creative task. Our Corporate Functionary needs to radically examine the conceptual and meaning structures of words, terms of reference, relation category . . . to restore the corporate discourse to its unified dimension, free from fragmented and departmentalized tendency institutionalized in teaching and in research in the institutions of business education. We need to liberate our narrative from the bondage of naturalistic ramifications.

Once again, it is an arduous task: to construct multiple narratives with relative contours and nuances by putting the "naturalistic" and taken for granted attitude in parenthesis for radical phenomenological reduction, to transcend its nominal concerns and to find meaning in wealth and riches, profit and personal gains, glory and fame, power and authority. Legitimization of power is illegitimate if it does not enjoy moral authority and power destroys itself if it is not predicated on truth. That is where the Corporate Thinker comes in; to assume the role that is his: "tell the stories, invent the narratives, revive the discourse and dream on."

However, given the overwhelming temptation awakened by the lure of mindset, generated by acquiescence - will such a dream come true? It is a forlorn hope. "Hope is a waking dream” (Aristotle). It unfolds a World within Word. It demands a culture that is not risk averse, a culture that promotes the will to truth, encourages the desire to think creatively, inspires the passion for innovative ideas and enlightened leadership, firmly entrenched in the thoughts of usable past, is propelled by the futuristic and transcendental vision.

That is the context in which we need to see the corporate world as it is, holding the promise of the world as it ought to be, the world within world, a dream within a dream, a circle within a circle. It is a reality with all its flaws and imperfections, ready to embrace the world to be, waiting to be awakened by the breath of love and loving care of education; above all, by the creative imagination and the will to truth. Let us hope that someday, ages and ages hence, miles and miles away, this world will glorify the realm of possibility and make our dream come true. That will be the day, and what a day will it be, when, after a long last the world to be, will manifest itself as a fulfilment of man's socio-cultural needs, ethico-moral propensities, political and economic aspirations. That will be the day when we will know, and for the first time, that this world has always been there, for the taking; but we will not have it. This world within the world in which we live, has always been there waiting for an imaginative interpretation by our creative will, to be rescued from its anonymity, to be awakened from its slumber. 
In this undertaking, apathy, lassitude, acquiescence, false sense of reality and feigning ignorance about it, fear, hatred, jealousy and prejudice, greed and resentment are venomous antithetical forces. These subjective impediments must be fought out to the end and absolute victory. The engagement produces a mindset with enormous consequences and dire moments of distress. With each failure and ineptitude, status quo consolidates its resources, enlarging its territories in the corporate landscape. Conceit, deception, lies, bad faith and greed become more and more stratified into significant and rampant adversities with all-consuming resolve to remain untainted by the questioning look. However small the victory and victory is never small by any measure, especially if it is on the battle field chosen by your adversary.

The renewed and the fiercest combat is now in defense of your mindset. In your mind, the goal is set with well-defined objective; the path to be taken and the direction too; forward and onward to the finish. "A man is finished not when he is defeated; he is finished when he quits.” (Mr. Richard Nixon)

As a narrative, it is an inflection point, reached as a consequence of our thinking and rethinking about the Corporate World - not piecemeal in a partisan make shift manner, or with the help of borrowed scaffoldings. But radically, co-creative and inter-subjectively; it is a constituency for change, reform, reconstruction and reconstitution, both as a coalesced silent minority and a vocal and articulate majority. This constituency is the reason, the meaning and the measure, of what the given world ought to be. They are the ones who live in the world within world and the dream they are dreaming offers an opportunity to craft a narrative that entails promises to be kept, barriers to be crossed, songs to sing. They live the task of confronting status quo by pushing the exclusive category "thus it is and it cannot be otherwise" to its farthest limit and hiding place. As a point of creative inflection, they impose upon the Corporate Functionary the task of negotiating between "thus it is" and "thus it ought to be" in our quest for the world to be.

Paradoxically, however, acquiescence, world weariness and benign indifference comes laden with an extremely powerful sense of certainty that future does not hold for you more than who you are and more than what you have. Hence, the "thus it is and it cannot be other than what it is." For some, it is far better than the painful certainty of knowing that you will always remain incomplete and unfulfilled. For man, as a journeying self, is it not better not to have embarked on the journey, knowing that after all the journeying, you are destined never to ever arrive, that you will always have "miles to go before you sleep"? The lure of such a mindset is hard to resist. Its charm works insidiously. It has a fascination hard to defy. It has its own logic and its tacit assumptions work mysteriously; in the silence of man's heart. They who are moved by it are forever encumbered by change. They love self-sameness; they celebrate permanence.

In dismay and despair, they who venture to enter the battlefield are the critics of such a world-view and mindset. They have noted that without yearning and a passionate desire for the world to be, we shall solve very few of our problems if we turn our back on change and movement in the corporate culture. Such an attitude leads to stagnation. It arrest the movement of a dynamic, creative, and progressive image of perfection that transcends the given world as it is, expanding our imagination of the way it ought to be. What is needed 
therefore is the creative discontent of human consciousness and the need to strengthen its internal movement towards the yet to be.

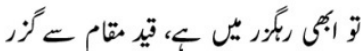

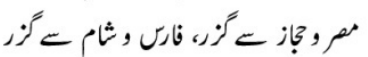

The internal movement of thought in Corporate Culture and the transcendental movement of consciousness both suggest that the "yet to be" extends beyond the "given", into the anticipation of its perspectival unfoldment - the "not yet", the occluded, the hidden and the obscure. It follows that no limit can be prescribed to it. It cannot be stigmatized into "it cannot be other than what it is." Its transcending nature follows an impulse which is always urging and beckoning us to something further and farther still. That is its strength but, from the naturalistic point of view, also its weakness. It sets up, an infinite ideal which, it is said, is impossible to realize.

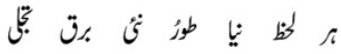

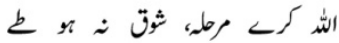

But, when we realize that man is a creature who has his being in the manner of becoming, it is bound to result in a radically altered attitude and a mindset with regard to our understanding of his being-in-the-world. It adds a new meaning to his hyphenated relationship to the world. With this radically changed outlook, man inhabits the world transcendentally, redefining the meaning of his being-in-the-world, pushing the limits of the worldliness of the world, farther and farther beyond the horizons of the "given" world. Now, with this new meaning of what it means to be in the world, acquiescence, world weariness, resignation to uncritical, unquestioning "thus it is and it cannot be otherwise" become simply matters of acceptance, rather than creative and evaluative judgments. Now, nothing goes without saying and nothing is taken for granted.

With this phenomenological attitude and the operative constitutive intentionality of man's consciousness of being-in-the-world, it becomes clear that consciousness is not only the consciousness of something, (the world, a person, a belief, an assumption, etc.), it is also, and at the same time, consciousness of something, as something, (as moral, or human, good or evil, just or unjust, etc.) In that point of intersection between the objective and the subjective is rooted the phenomenon of interpretation. All experience, like all consciousness, is interpreted experience. It is experience of something as something. In that moment of encounter are hidden the multiple narratives pertaining to truth and reality, value and judgment, thought and emotions . . . and the whole gamut of man's being-in-the-world, highlighted and underplayed, by man to keep the changing variations in perspective. That is when we see not a different world but the same world differently. What we see now is the "given" world as it can be and therefore ought to be. That is the meaning we give to the world to be.

Now, his being incomplete does not cause man to grieve or to lament; rather, it results in a joyous wisdom and a shared sense of his being a human being. He does not feel embarrassed over his not being what he is capable of becoming. Rather, he draws courage and strength from his consciousness of human predicament and an inborn and intrinsic sense of his being a member of the community of ends, dialogically and inter-subjectively, engaged in creative and co-creative acts with due respect for the humanity of man and the frailties of human nature. 
A new man is born with a new worldview, a new mindset and the consciousness of what it means to be a human being. It unleashes tremendous creative energy, freedom and liberty, a restlessness of being in the manner of becoming.

$$
\begin{aligned}
& \text { موجيم كم آسورك، } 6 \text { عرم است }
\end{aligned}
$$

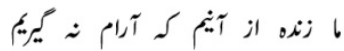

In its influence, it is a momentous discovery and an event of tremendous significance. After the event, neither the life of man, his worldview or his place in the world is ever the same again. It is like the revelation of "I am".

"Only that truly exists which can say 'I am? It is the degree of the intuition of 'I amness' that determines the place of a thing in the scale of being."

Iqbal, M. The Reconstruction of Religious Thought in Islam, P.45

The maladies of Corporate Executive are many and deep and the virtues he embodies are very few and superficial. His maladies are rooted in the field of his consciousness and his world-view is flawed with grave and fatal problems. Among others, they pertain to the

- Loss of center of value

- Loss or a diminished sense of selfhood and, a

- Gradual eclipse and disappearance of transcendence from the worldliness of his world.

In this context, the need to reshape and redefine the corporate narrative gains an added urgency. It can be delayed at the cost of grave consequences. It cannot be postponed indefinitely without minimizing the role of the institutions of business education in crafting public attitudes and without undermining their corporate ethos. It is of utmost importance for us, teaching in the schools of business education, to have a clear perspective on how the corporate discourse addresses these issues by developing the concepts of virtue, nobility and character, particularly in relation to decision making, and the exercise of power and authority in the corporate management. It is therefore important to remember that whosoever exercises authority and power in the Corporate System, decide, by his own will, to act as "a member of a Kingdom of ends" and a stake-holder in a shared 'moral order'. Equally important for us is to have a clear view about how our corporate narratives can help us transcend accumulative calculus and quantitative expansion of self-interest and profit motive. Equally important is an understanding of the ontological flaw inherent in the role of propositional logic in corporate thinking. Propositional logic is based on propositional statements. It is concerned with the logical and linguistic validity of proposition, without making any existential claims. But, "sugar is sweet" is not a sweet proposition. And yet, "he who has tasted, knows", is a refrain from Imam Ghazali. Knowledge is the taste of knowing. Knowledge as an instrument of a social action and education a vehicle of cultural change are both integrally related as aspects of man's ontogenetic evolution. In life, it is the ontogenetic aspect of knowledge (Knowing as Being) that matters. Such knowledge is an existential event a challenge to man's creative will and an apotheosis of his moral and ethical valor. It imposes upon our students, as seekers of knowledge, the heroic task of proving to themselves, that man is not a Leviathan, by living in contradiction to

"Man is a wolf to his fellow man."

(Hobbes) 
Education in its intellectual, ethical, moral and imaginative intensity must, ultimately, lead to the revelation that art, philosophy, liberal ideas and humanistic proclivities do not grow in isolation. Together and in conjunction with others, each one of these components of the corporate culture deepens and enlarges the unified and unifying existential and experiential view of knowledge. A transcendental perspective helps us realize that each element should be understood separately and together as a gestalt, to craft public attitudes. It impresses upon the mind and the heart of the corporate executive that "stewardship is of total management". Ethical development and the politics of corporate experience too, used as the indicators of change, determine the nature and scope of corporate governance. They make us see how they impact upon each other and, together, how they can be used to make lasting and positive changes in the totality of the corporate system and in any one of its components. Thus, using change and movement as the dominant metaphors, juxtaposed in unison with the transcendental view of life and corporate reality, Corporate Functionary can arrive at a radically whole new way of looking at man's being-in-the-world. This will provide him an insight into human nature and how the worlds exist within worlds and how the worlds exist within the world

Alexis Carrel wrote Man, the Unknown in 1935. A remarkable book, for more than many reasons. In the first chapter: The Need of a Better Knowledge of Man, Carrel says:

"Naturally, all these sciences arrive at a different conception of their common object. They abstract only from man what is attainable by their special methods. And these abstractions, after they have been added together, are still less rich than the concrete fact . . . Man, as known to the specialists, is far from being the concrete man, the real man . . . But he is also the poet, the hero, and the saint ... also the tendencies, the conjectures, aspirations of humanity.”

Much later, on p.286, in the Chapter on The Remaking of Man, Carrel says:

"Why should not some individuals sacrifice their lives to acquire the science indispensable to the making of man and his environment? ... The weakness of many of the scientists whom we meet in universities and laboratories is due to the mediocrity of their goal and to the narrowness of their life. Men grow when inspired by a high purpose, when contemplating vast horizons. The sacrifice of oneself is not very difficult for one burning with the passion for a great adventure. And there is no more beautiful and dangerous adventure than the renovation of modern man.”

This is how all great men live. In his On Heroes, Hero Worship and the Heroic in History, Thomas Carlyle calls them "beginners". "A great man is a beginner precisely because he sees further than others and desires things more strongly than others."

Carlyle's Hero belongs to two worlds and dwells in a world within World. He has a clear vision of what needs to be seen; our dimly visualized ideas. He feels more intensely; e.g., our half felt emotions, the things we love or do not hate. He is the medium. He does not gloss over the present fault lines while searching for the future possibilities. 
Carlyle's Hero Worship and the Heroic in Human Affairs converge upon the lives of those who believe and are inspired by an ideal larger and superior to their circumstances in life. By their mindset, they are galvanized into a perpetual struggle between their creative will and the forbidding adversities of their being-in-the-world. Their creative will, e.g., the will to truth, renders obsolete the belief that things grow better continuously and constantly. How many times have we been betrayed by the belief in linear progress as a constant improvement over the previous and past stages of development? To believe that the future or human destiny is predetermined by the "moving finger" is to believe fait accompli. It is taken for granted, as irrevocable.

Carlyle's Hero is the medium and it is his historic role in and through him are meditated and facilitated the tensions and distresses, conflicts, hopes and despair of his time. "Carlyle wrote emotionally his language expressed passion; love, hate, enthusiasm, or scorn; nothing left him unmoved, not even death.”

Carlyle constructed his discourse on Heroes and Hero Worship in dire contrast to personality cult to make the nobility of their character, invincibility of their self regard and pristine and distinct perception of their own-ness, their defense against inauthentic modes of being, particularly the temptation to capitalizing on the inheritance of the culture of patronage and nepotism. They are not, by virtue of their heroic attitude and mindset, share holders in any enterprise built upon adulation, psycophancy and beaurocratic temptations of our times.

Like immoral Kant, Carlyle was a staunch critic of Pure Reason. He had no taste for scientism and its objective acting culture. He detested intellectual obstructions and philosophical aloofness. Reality, he believed, must have a human face and our being-in-theworld must beautify the human metaphor. Our Corporate Thinker believes that it will not be a rash assumption to say that it is Carlyle's narration on corporate reality with strong reservations about abstract, speculative metaphysical thinking, detached from the "world making" and "world shaking" acts. Like Nietzsche and Marx, Carlyle believed that the first, and primary task of a philosopher is to think that the thoughts about changing the world to make it better. To phrase it with Iqbal's admonition

and the eloquence of Faiz:

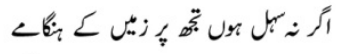

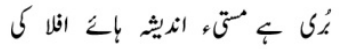

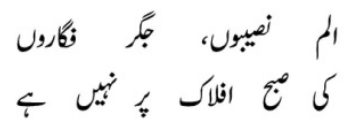

To this end and for that reason Carlyle's philosophical writings and narratives are strikingly different from those of Locke Hume, Macaulay, Pope and Fielding. He lived in the same world with them but differently; in his own way. Reverence for truth and love of wisdom are the criteria of judgment and the standard of criticism of all socio-cultural, ethical and moral, politico-economic, existential and religious criticism. Class distinctions, religious sectarianism, ethnic stratifications, partisan politics, corporate exploitation, trade unions are, one and all, "artificial products of human arrogance." The worlds within the world are inhabited by those who walk like angels and talk like angels but are devils in disguise. 
Human condition can be made better and human situation must be improved as an imperative but not through such artificially and arrogantly construed "misfortunes of modern life". Our salvation lies in the continued spiritual refinement and increased educational development of the masses.

\section{Carlyle writes:}

We have undertaken to discourse here for a little on Great Men ... What ideas men formed of them, what work they did; . . what I call Hero- Worship and the Heroic in human affairs. For, . . . the history of what man has accomplished in this world is at bottom the History of the Great Men who have worked here. . . all things that we see standing accomplished in the world are properly the outer material result, practical realization and embodiment of Thoughts that dwell in the Great Men sent into the world: (Lecture1).”

Today, what ideas do we need from our "Great Men" and the "work they did" and the things they accomplished if we look at the Corporate Pakistan or the corporate world from inside out or outside in. We see a great deal of clutter outside and too much rot within. Who will do all the mopping and cleaning? Our corporate world is full of things that need to be undone; it is full of empty spaces that need to be filled with memories and fleeting moments of thoughts and ideas for tomorrow, if tomorrow comes. But, who will do the thinking and imagining? Who will dare to ask painful questions? Who will sing the sweet songs which tell us of saddest thoughts?

What kind of people do the kind of things we have done to ourselves? What kind of people are they who do not do to themselves, the things we have denied to ourselves? Who should we ask?; our Heroes. Our Great Men, our leaders, our teachers, our mentors, our guides, our parents - dead or alive? There, in that crone, over there, attended by years of neglect and discards rest out heritage - remains of the years of wasted youth, intelligence, discovery and culture; accumulated sorrow, grief, resentment, regret and shame, remembrance of the things we did not do but could have done and things we did but have forgotten to remember. Here, over here, rest and assortment of legacies and heresies: legacy of a hero who gave us PIA, our National Flag Carrier, the great people used to fly with. Not anymore. The man who gave us wings to fly through the wooly clouds and immense skies, to the far off places beyond the hills and high mountains, rain forests and thirsty deserts, lands and places beyond the last horizon, we never thought existed, that men, is gone. He is long gone but his legacy lingers on.

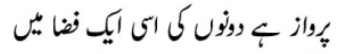

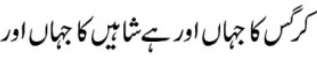

It is so long now that we have been heading in the wrong direction, even in those rare times of our journey, when, perchance, we were on the right path, moving in, what we thought, was the right direction. We never thought wrong detours can make the journey longer many times, time wise, and that in life, time is our scarcity. We never tried to understand our failing into the yet to be. To embark on the journey, it is necessary to know that the shortest distance between the two points is the straight line. Journeying is an adventure. In life, it is not wise to laugh at things which can make us cry, if we take time to think a little live a bottle to die a little to cry a little. Today, if we look at ourselves from 
where we are standing, to think our thoughts and to sing our song, we may in anguish and sorrow, realize the importance of retrospective wisdom.

$$
\text { فاصل }
$$

We live in two worlds, the world we are trying to escape from and the world we are dreaming of. This overriding moment of transcendence, however brief, is a flicker of light, resulting in the eclipse of naturalistic perspective and the advent of the "world to be". This moment of transcendental orientation is an experience of a lifetime. He who is touched by it is never the same person ever again. It is an experience the Zen Buddhist call Satori. It provides a new framework and a new paradigm for our being-in-the-world. It brings into focus the yet unknown profiles of our being a human being, a new way of looking at things and new ways of doing what needs to be done can be done and therefore ought to be done.

Tufail A. Qureshi

We must welcome the future, remembering that soon it will be the past; and we must respect the past, remembering that it was once all that was humanly possible.

George Santayana 